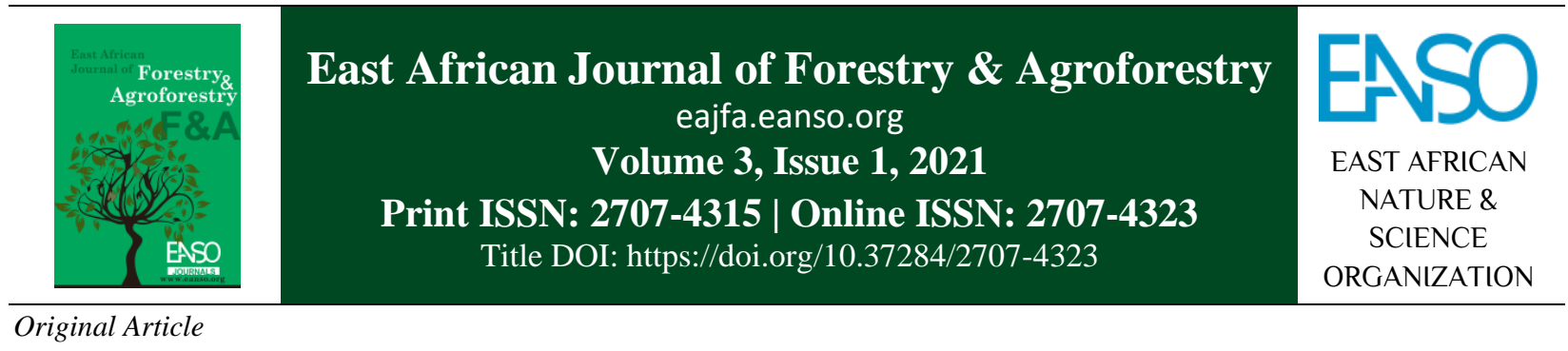

\title{
Farmers' Perception of Coffee Agroforestry Systems in an Area Targeted for Organic Certification in Burundi
}

\author{
Soter Ndihokubwayo ${ }^{*}$, Tharcisse Havyarimana ${ }^{l}$, Sarah Windbühler ${ }^{2}$, Sanctus Niragira ${ }^{l}$, Bernadette \\ Habonimana ${ }^{1}$, Salvator Kaboneka ${ }^{1}$ \& Heidi Elisabeth Megerle ${ }^{2}$ \\ ${ }^{1}$ Doctoral School of the University of Burundi \& Environmental Science and Technology, Faculty of Agronomy and Bio- \\ Engineering, University of Burundi, P. O. Box 2940 Bujumbura, Burundi. \\ ${ }^{2}$ Hochschule für Forstwirtschaft Rottenburg am Neckar, Rottenburg am Neckar, Germany. \\ * ORCID: https://orcid.org/0000-0001-5038-8128; Author for Correspondence email: soter.ndihokubwayo@ub.edu.bi.
}

Article DOI: https://doi.org/10.37284/eajfa.3.1. 352

Date Published: ABSTRACT

01 July 2021 Taking into account the current understanding of a system by farmers is an important starting point in every project aiming at the economic and

Keywords: social development of human beings. In the process of organic certification of coffee growers, training sessions on various topics are

Coffee, conducted. In addition to these sessions, there are field visits to farms by Agroforestry, experts. And it is most often done through a top-down approach. A Cooperative, household survey was carried out on a purposive sample of households Certification, in the zone of the central plateaus in Burundi. Data were collected using Soil, a questionnaire through smartphones. Data analysis was carried out

Biopesticide, using IBM SPSS Statistics software by calculating means, frequencies Central plateaus, and cross-analyses of variables. Results show that, besides bananas that Burundi. are deliberately considered as shading crops, Grevillea robusta is the most frequent shade tree which is present on $62 \%$ of coffee plots. It is followed by an indigenous tree: Ficus sp. which is present on $14.6 \%$ of plots, and a fruit tree, Persea americana present on $13.9 \%$ of plots. The effects of shade trees on soil properties are well recognized by farmers. For their search of certification (75\% of farmers are involved in the process of organic certification), chemicals application is banned. Farmers use a locally-made biopesticide decoction. They prepare it from a set of five plants: Tephrosia vogelii, Solanum aculeastrum, Neorautanenia mitis, Capsicum frutescens, and Tithonia diversifolia. This research has proven that the integration of shade trees in coffee plots is a reality in the region.

40 This work is licensed under a Creative Commons Attribution 4.0 International License. 


\section{APA CITATION}

Ndihokubwayo, S., Havyarimana, T., Windbühler, S., Niragira, S., Habonimana, B., Kaboneka, S., Megerle, H. E. (2021). Farmers' Perception of Coffee Agroforestry Systems in an Area Targeted for Organic Certification in Burundi East African Journal of Forestry and Agroforestry, 3(1), 40-53. https://doi.org/10.37284/eajfa.3.1.352

\section{CHICAGO CITATION}

Ndihokubwayo, Soter., Tharcisse Havyarimana, Sarah Windbühler, Sanctus Niragira, Bernadette Habonimana, Salvator Kaboneka and Heidi Elisabeth Megerle. 2021. "Farmers' Perception of Coffee Agroforestry Systems in an Area Targeted for Organic Certification in Burundi". East African Journal of Forestry and Agroforestry 3 (1), 40-53. https://doi.org/10.37284/eajfa.3.1.352.

\section{HARVARD CITATION}

Ndihokubwayo, S., Havyarimana, T., Windbühler, S., Niragira, S., Habonimana, B., Kaboneka, S., Megerle, H. E. (2021), "Farmers' Perception of Coffee Agroforestry Systems in an Area Targeted for Organic Certification in Burundi", East African Journal of Forestry and Agroforestry, 3(1), pp. 40-53 doi: 10.37284/eajfa.3.1. 352.

\section{IEEE CITATION}

S. Ndihokubwayo, T. Havyarimana, S. Windbühler, S. Niragira, B. Habonimana, S. Kaboneka, H. E. Megerle, "Farmers' Perception of Coffee Agroforestry Systems in an Area Targeted for Organic Certification in Burundi”, EAJFA, vol. 3, no. 1, pp. 40-53, Jul. 2021.

\section{MLA CITATION}

Ndihokubwayo, Soter., Tharcisse Havyarimana, Sarah Windbühler, Sanctus Niragira, Bernadette Habonimana, Salvator Kaboneka and Heidi Elisabeth Megerle. "Farmers' Perception of Coffee Agroforestry Systems in an Area Targeted for Organic Certification in Burundi". East African Journal of Forestry and Agroforestry, Vol. 3, no. 1, Jul. 2021, pp. 40-53, doi:10.37284/eajfa.3.1. 352 .

\section{INTRODUCTION}

The first introduction of coffee in Burundi was around the $1920 \mathrm{~s}$ by the German authority (Nyamoya, Kazungu \& Akilimali, 1986). But the first efforts to spread out coffee throughout the hills of Burundi date from the 1930s during the Belgian supervision (Bidou, 1994). Currently, in Burundi, only the species Coffea arabica is grown. Coffea canephora, named "robusta coffee" was cultivated in the Imbo plain (near the capital Bujumbura) but it has been completely replaced by the oil palm.

Coffee is one of the most important tropical agricultural commodity worldwide, cultivated in more than 70 countries (De Beenhouwer et al., 2015) while (Toledo \& Moguel, 2012) mentions 85 countries. It is the most traded commodity globally by developing nations after petroleum oil (Munyuli, 2011). Coffee is a very important crop in the life of Burundi and Burundians. Indeed, coffee occupies a prominent place as an export crop. In years of good production, coffee represents more than $80 \%$ of foreign exchange receipts; and 50\% during years of poor production. At the level of the Burundian coffee grower, the income from the sale of coffee is interesting because of their grouped nature. Indeed, the coffee grower receives amounts that he is not able to save throughout the year. The sales periods called "isizeni" or season are really times of popular jubilation. This is the time when women receive new loincloths. In addition, Kimonyo and Ntiranyibagira (2007) assert that with the rise of the rural micro-credit system, owning a coffee plantation is the main credible guarantee that the farmer can offer to microfinance institutions.

Since its introduction in Burundi, coffee has been grown in monoculture without any association with trees or crops. This system is called sun-exposed coffee growing. It requires intensive management practices especially those related to soil fertility and moisture conditions by applying a certain amount of mineral fertilizers, and by mulching. This was done through a very coercive system that did not generate much enthusiasm for this "Government" crop according to Hatungimana (2008).

Burundian farmers possess century-old experience and know-how in coffee growing. During this time, and thanks to the State's withdrawal from the coffee sector in the 1990s, coffee producers have organized themselves into associations to make their voices heard. They have had some influences and currently there are positive changes towards sustainable coffee management in Burundi, such as the association of shade trees and food crops with coffee. 
In the past, agronomic trials on the association of coffee with shade trees as well as with food crops had been conducted in Burundi. But their results have not been published. Still, the results were encouraging. For example, the growth of coffee trees was not affected by the presence of the bean; there was even a tendency to have more vigorous coffee plants in coffee trees associated with beans (Nibasumba, 2013).

Meanwhile, the attitudes of consumers have changed. They are more discerning about the coffee products they choose in terms of sustainability issuing social, economic and environmental problems. This led to the establishment of various certification systems for sustainable agricultural production as Fair Trade and organic certification which are often combined.

This movement of coffee growers organized in federative associations also helps people in the process of organic certification. Organic certification is an integrated management system that promotes sustainable, healthy and ecologically sounded production. On one hand, it bans the use of fertilizers, pesticides, animal drugs and food additives that may have adverse health effects. On the other hand, it promotes every natural practice that enhances the soil structure and fertility, prevents soil erosion and promotes biological diversity (FAO, 2015).

An organic certification process is a farmer-based approach in the sense that it promotes the use of local resources, local knowledge, the connection between farmers, consumers and their markets (FAO, 2015). Indeed, if we want farmers to change their practices into a certifiable organic management system, the trainers and other supervisors must first understand farmers' local knowledge systems (Grossman, 2003).

For Burundi, the organic coffee certification was introduced by the "Union des Coopératives des Caféiculteurs" (COCOCA). COCOCA works in collaboration with a German certifying organization named Naturland. This organization has an internationally recognized wealth of experience in certification where, in 2005, over 34,000 of its 36,000 certified farmers were from countries from the so-called Third World (González \& Nigh, 2005).
Practically, to get the organic certificate, farmers must clearly demonstrate for years, that they have subscribed to the non-use of chemical fertilizers, synthetic pesticides and, above all, that they have integrated shade trees in their coffee plantations. The Mboneramiryango and Nyarunazi cooperatives from Gitega and Muramvya respectively are advanced in the search for organic certification.

The scientific community agrees that the integration of trees and crops and/or animals into an agroforestry system leads to sustainability through many benefits on soil, water resources, biodiversity and carbon sequestration (Cerdán et al., 2012). For details, a list of the advantages, disadvantages and desirable characteristics of shade trees for coffee, cacao and tea is given in Beer (1987).

The introduction of organic certification among Burundian coffee producers may be one of the solutions to the wretched prices that are granted to them. Elsewhere, organic products have proven to be a source of impressive returns for farmers. Generally, profits from organic coffee are often 15 20\% higher than non-organic products (FAO, 2015; Grossman, 2003).

It is in this framework that this paper analyses the farmers' perceptions towards the organic certification and advantages of the integration of trees in coffee plots in terms of soil conditions, quality of coffee, and pests and disease management.

\section{MATERIALS AND METHODS}

\section{Study Area}

The study area is located in the Central plateaus agroecological zone of Burundi. Burundi is composed of five main ecological zones: Imbo, Mumirwa, Congo-Nile crest, Central plateaus, and eastern and northern depressions. Amongst the five zones, the zone of the central plateaus is the largest, having about $52 \%$ of the total area of the country. It lies from $29^{\circ} 34^{\prime} 7.5^{\prime \prime}$ to $30^{\circ} 45^{\prime} 11^{\prime \prime}$ East and $2^{\circ} 34^{\prime} 49.7^{\prime \prime}$ 'to $3^{\circ} 59^{\prime} 19^{\prime \prime}$ ' South (Figure 1).

An analysis of the Burundi soil map for the only central plateaus region shows a dominance of Ferralsols which represent $50.5 \%$ of the total area, followed by Ferrisols with $24.5 \%$. There is a 
remarkable presence of rock outcrops up to $11.6 \%$ of the total area of the zone of the central plateaus. The INEAC soil classification as in Tessens et al. (1991) is used in this paper. Ferralsols and ferrisols generally exhibit poor chemical fertility levels. Also, the overexploitation of soils on steep slopes leads them to more vulnerability to water erosion.

As it is for the whole of Burundi, the zone of the central plateaus is dominated by subsistence agriculture in which food crops have a high level of diversification. You can find up to five crops on one small piece of land (beans, maize, banana, taro, cassava, etc.). There are also cash crops, the most important of them being coffee, followed by tea.

The zone of the central plateaus has cool weather, with an average temperature of $20{ }^{\circ} \mathrm{C}$. The region has a humid tropical climate tempered by altitude, which is said to be one of the reasons for the high population density in the region. In general, the rainy season lasts about 8 months and the dry season 4 months. The annual rainfall varies between 1,200 and 1,500 $\mathrm{mm}$ (Niragira et al., 2015).

The region has a bimodal rainfall pattern, which allows three cropping seasons per year. The first rainy season (A), known as Agatasi, occurs between September and January. The second season (B) is called Impeshi and lasts for 5 months from February to June. A short dry season (with less frequent and intense precipitation) is observed between these two rainy seasons from mid-January to mid-February and is called Umukubezi. The third cropping season (C), called Ici, occurs between July and September. In this dry period, farmers mainly grow vegetables, beans, maize, potatoes, and off-season crops such as rice in wetlands and river valleys (Niragira et al., 2015).

In terms of administrative organization, Burundi is divided into 18 provinces, and each province is divided into communes. This research has been conducted in Ngozi, Gitega and Muramvya Provinces; and in Busiga, Giheta and Rutegama Communes (Figure 1). 
Figure 1: Location of the Study area

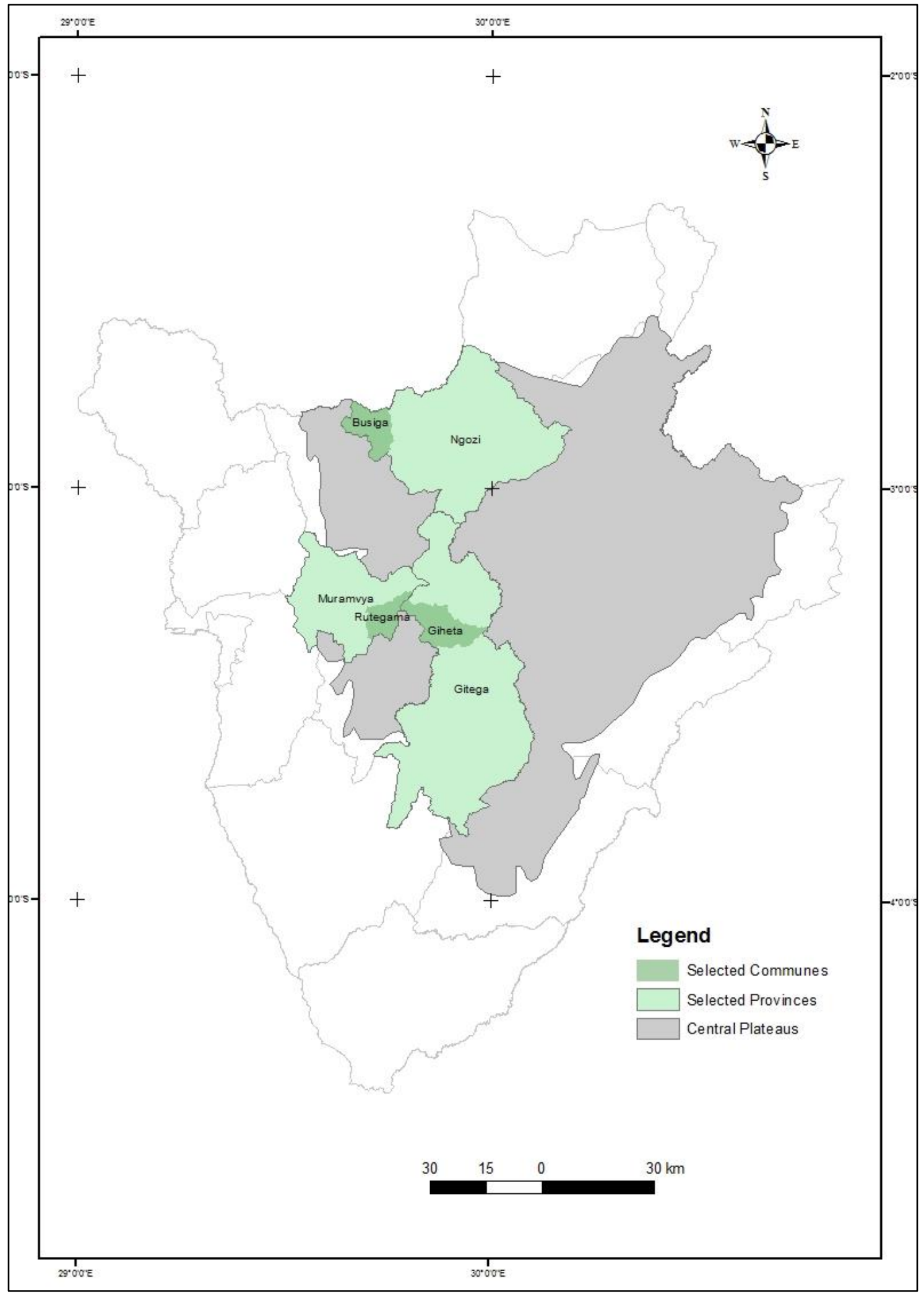

44 | This work is licensed under a Creative Commons Attribution 4.0 International License. 


\section{Research Design}

We conducted a household survey because decisions about the farming system are taken at the household level. The purposive sampling technique was used. The total population was farmers that are members of coffee cooperatives grouped into COCOCA. 3 cooperatives (Ubwizabwikawa, Mboneramiryango, and Nyarunazi) were selected respectively in Ngozi, Gitega and Muramvya Provinces.

The target population was known from the list of all members of the cooperatives. A total of 1,873 farmers were recorded on the COCOCA's list. When distributed over the three cooperatives, there were 489 households for the Ubwizabwikawa cooperative, 803 for Mboneramiryango, and 581 for Nyarunazi. For this study, we considered adding a control population. This population was composed of farmers (20\%) who are not members of COCOCA. The total target population was then 2,248 households.

The sample size was computed within a confidence level of $95 \%$. The confidence level tells how accurately a sample reflects the total population being studied. This corresponds to a $1.96 \mathrm{z}$-score value for the normally distributed population. The finite population correction formula for proportions as detailed in Israel (1992) was used. This yielded 329 farmers to be interviewed. For each cooperative, the number of farmers to be selected was determined in proportion to its contribution to the total population. Thus, 86 households were selected from Ubwizabwikawa cooperative, 141 households from Mboneramiryango cooperative, and 102 households from Nyarunazi cooperative. During the survey, since we had a little time left, 6 more persons were interviewed, leading to a total of 334 respondents. This does not hinder the work in any way, since the formula gives the minimum sample size to consider.

All the households were purposively selected from the COCOCA's members list using the systematic sampling method for each cooperative. A systematic sample is obtained by selecting a random start near the beginning of the population list and then taking every unit equally spaced thereafter (Bellhouse, 2014).
A questionnaire was developed, pretested and then administered to each household. This instrument was used to collect data on general socio-economic status, Agroforestry tree species in coffee, intercrops, pest management using locally made products, and many other items. For the questions related to certification, 100 households ( 80 being COCOCA members and 20 not) were selected from the sample on the basis of volunteering during a second survey.

The household heads were qualified to answer our questions. If not present, their spouses could replace them. Local guides were of great importance in taking the interviewers to the selected households. Interviewers were recruited mainly based on their mastery of the questionnaire administration, and their mastery of the two languages (French and Kirundi). The questionnaire was written in French, the questions were asked in Kirundi, and the answers transcribed in French. The translation was almost simultaneous. Interviewers were trained before the fieldwork, and the administration of the questionnaire was directly conducted using smartphones via the Kobo collect software.

Key informants were also contacted by the supervisor of the survey to triangulate information from household interviewees. Key informants were elderly persons having experience in coffee growing with shade trees. The discussions were about the importance of agroforestry in coffee plots. During the field visits to households and coffee plots, personal observations were made. Shade tree species present in coffee plots, the management of coffee and shade trees were observed.

Since data collected using smartphones are stored on a server, their download permits the researcher to begin their analysis. Quantitative data analysis was done using SPSS software where descriptive statistics (mean, standard deviation, frequencies, etc.) were computed. Qualitative analysis was also done for data from the key informants.

\section{RESULTS AND DISCUSSION}

\section{Socio-Demographic Aspects}

Analysis of the data gives the average age of farmers who grow coffee in the area to be 55 years. We conclude that those who own coffee trees are elderly 
persons. This might constitute a limitation to new environmentally and socially sustainable practices in coffee systems in the future, as younger generations are gradually losing interest in coffee production.

Of the 334 interviewees, $31.1 \%$ were female and $69.9 \%$ were male. This proportion of women heads

\section{Table 1: Farmers' Education Levels in the Study Area}

\begin{tabular}{lll}
\hline Education level & Number & Percentage \\
\hline No formal education & 80 & 24.0 \\
Alphabetization & 70 & 21.0 \\
Primary school & 161 & 48.2 \\
Fundamental & 17 & 5.1 \\
Handicrafts & 3 & 0.9 \\
Post-fundamental & 3 & 0.9 \\
Total & $\mathbf{3 3 4}$ & $\mathbf{1 0 0 . 0}$ \\
\hline
\end{tabular}

The Burundi national education system is structured on a 9-3-3 model: nine years of basic education (called fundamental), three years of secondary school (named post-fundamental) and a three-year undergraduate curriculum. This model was introduced in the 2013-2014 school year. Those who do not manage to pass the fundamental level follow a vocational education that allows them to integrate into socio-professional life. The education level is very low for coffee growers. Nearly, all the farmers $(99.1 \%)$ have the level below primary. It makes it clear that extension services and others in charge of the transfer of innovation in rural areas will have to make a lot of effort to get their messages across.

Table 2: Farmers in the Process of Organic Certification and those Willing to Continue

\begin{tabular}{lcl}
\hline Being in the Process of Organic Certification & Willing to Continue with the Process \\
& 58 & 35 \\
TOTAL & 42 & 40 \\
\hline
\end{tabular}

We wanted to investigate the reasons why a farmer wants to continue with the process of organic certification. Results are in Figure 2:

46 | This work is licensed under a Creative Commons Attribution 4.0 International License. 
Figure 2: Reasons to Continue with the Organic Certification Process

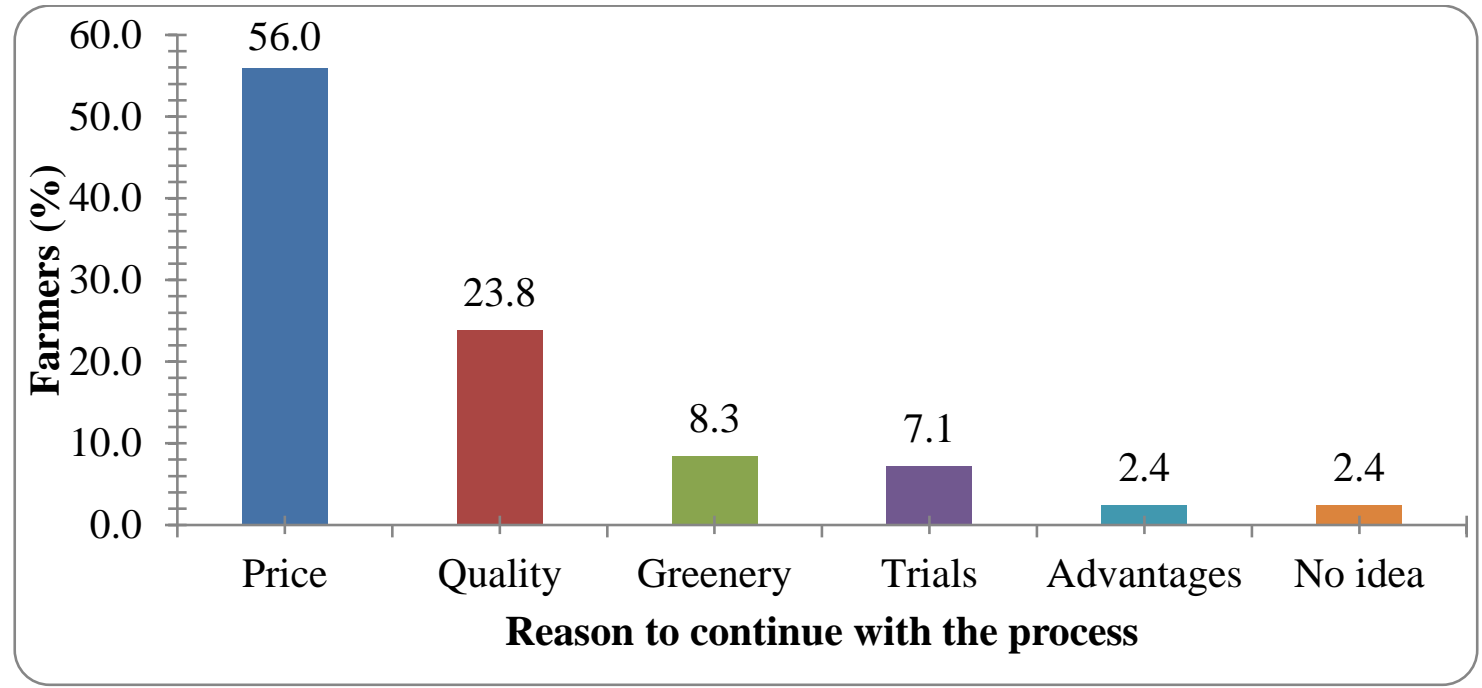

The price of coffee cherries is the main reason for most farmers $(56 \%)$ to continue with organic farming. It is followed by the quality of cherries for $23.8 \%$ of farmers. The two reasons indicate how much farmers are driven by the improvement in the monetary revenue, as good quality leads to much money. There are farmers $(8.3 \%)$ who give the higher foliage production as their reason for continuing organic farming, while others $(7.1 \%)$ want to try organic farming because they want to find out if it is profitable. The delivery of premium prices for quality coffees has been identified as critical issues for the sustainable development of the coffee sector and human well-being in developed and developing countries (Kufa, 2010).

\section{Coffee-based Agroforestry}

This study was conducted among farmers who own coffee plots. Since a farmer can possess more than one coffee plot, a total of 874 coffee plots were recorded. On average, each farmer owns 2.8 coffee plots. A large proportion of farmers has 3 plots $(24.6 \%)$ or 4 plots $(12 \%)$. Some others have more than 4 plots and some few can even go up to 15 plots. The mean number of coffee bushes is 372.5 per farmer on an average area of 2,309.9 $\mathrm{m}^{2}$.

We found one or more shade trees in 610 coffee plots representing $(69.8 \%)$. Bananas are put together with shade trees because it provides shade to coffee trees. We give the first four genes of the tree species which are present in more than $10 \%$ of the coffee plots with shade trees, in the following sequence: Musa sp. (63.5\%), Grevillea robusta (62\%), Ficus sp. (14.6\%), and Persea americana $(13.9 \%)$. Some other trees are scattered throughout some coffee plots (Table 3): Maesopsis eminii, Calliandra calothyrsus, Markhamia lutea, Cedrela toona, Cordia africana, Leucaena leucocephala, Tephrosia vogelii, Polyscias fulva, Albizzia stipulata, Entandrophragma excelsum, and even Eucalyptus sp.

Table 3: Shade Trees Present on Coffee Plots

\begin{tabular}{ll}
\hline Shade tree & Coffee plots $(\%)$ \\
\hline Musa sp. & 63.6 \\
Grevillea robusta & 62.1 \\
Ficus sp. & 14.6 \\
Persea americana & 13.9 \\
Maesopsis eminii & 6.7 \\
Calliandra calothyrsus & 6.6 \\
Markhamia lutea & 4.3
\end{tabular}

47 | This work is licensed under a Creative Commons Attribution 4.0 International License. 
East African Journal of Forestry and Agroforestry, Volume 3, Issue 1, 2021

Article DOI: https://doi.org/10.37284/eajfa.3.1.352

\begin{tabular}{ll}
\hline Shade tree & Coffee plots (\%) \\
\hline Cedrella toona & 3.0 \\
Cordia_africana & 0.7 \\
Leucaena leucocephala & 0.5 \\
Tephrosia vogelii & 0.5 \\
Polyscias fulva & 0.3 \\
Albizzia stipulata & 0.3 \\
Entandrophragma excelsum & 0.2 \\
Eucalyptus sp. & 0.2 \\
\hline
\end{tabular}

For the sake of food security, farmers willingly leave bananas (Musa sp.) in their coffee plots, as well as avocado trees (Persea americana). Bananas are consumed as banana wine, as a dessert, or in the cooked form. All these forms are sold in the market. Bananas are therefore an important source of family income. Banana leaves and pseudo stems are used as mulch in the coffee plots. This recycling aspect is very important in agroforestry. Grevillea robusta is found in many farms because this tree has long been popularized by forestry services. Besides its wood which is of good quality, its branches also serve as crop stakes. This is probably the reason why many G. robusta trees are pruned to near the top. Avocado (P. Americana) fruits are widely consumed by the population, which is a solution to malnutrition by providing good fats. Ficus sp. is an indigenous tree. In the study area, two species, $F$. thonningii and $F$. vallis-choudae were found. Ficus $s p$. has several uses. During the dry season, it serves as food for the small ruminant animals that no longer have where to graze. In coffee trees, $F$. thonningii stays green in the dry season. Culturally, a species, $F$. thonningii was used in the manufacture of traditional clothes.

For the farmers, shade trees provide some advantages to coffee bushes. Figure 3 gives the main advantages of the association of trees and coffee:

\section{Figure 3: Advantages of Shade Trees on Coffee Plots as Seen by Farmers}

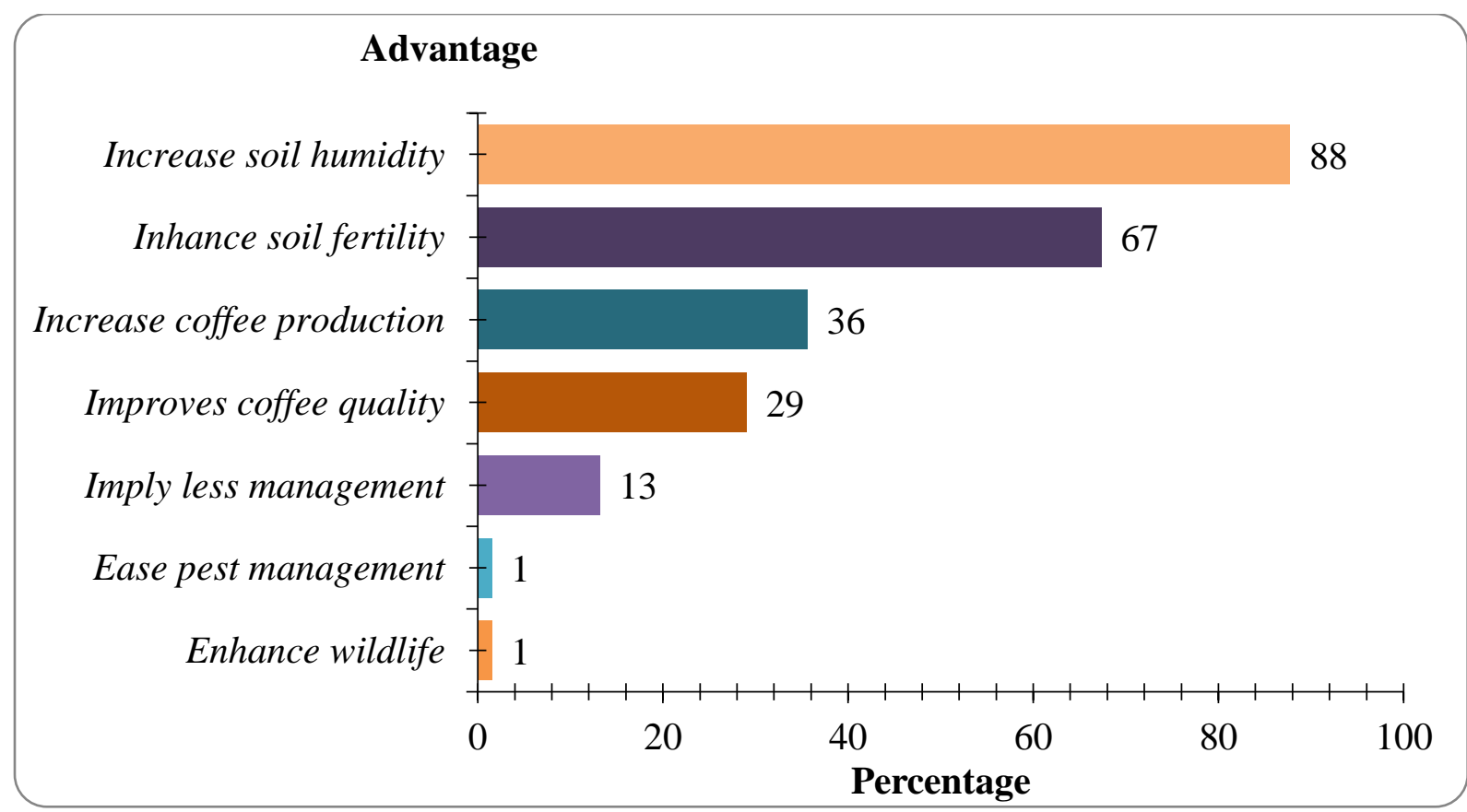

Benefits related to soil conditions such as increasing soil moisture as well as improving soil fertility are well recognized by farmers. Contrariwise, opinions on the effects of shade trees on increasing coffee production as well as on improving coffee quality are mixed. Some farmers accept that the presence of

48 This work is licensed under a Creative Commons Attribution 4.0 International License. 
shade trees reduces the work of coffee management, especially for weed management. Among the possible advantages of including shade trees with perennial crops, Beer (1987) has included the suppression of weed growth. This is close to results from research carried out in Costa Rica, where farmers clearly stated the effect of shade trees in reducing weed pressure (Cerdán et al., 2012).

Some food crops are deliberately left in the coffee plots. A total of 112 coffee plots, representing
$12.8 \%$ have one or more intercrops. The first five main intercrops based on the number of plots in which they have been observed are beans (Phaseolus vulgaris) that are found in 67\% of the plots having intercrops, taro (Colocasia esculenta) in $17 \%$, maize (Zea mays) in $15.2 \%$, potato (Solanum tuberosum) in $9.8 \%$ and cassava (Manihot esculenta) in $8 \%$. Details are given in Figure 4. The other crops are squash (Cucurbita sp.) and eggplant (Solanum macrocarpon).

\section{Figure 4: Food crops used as intercrops with coffee}

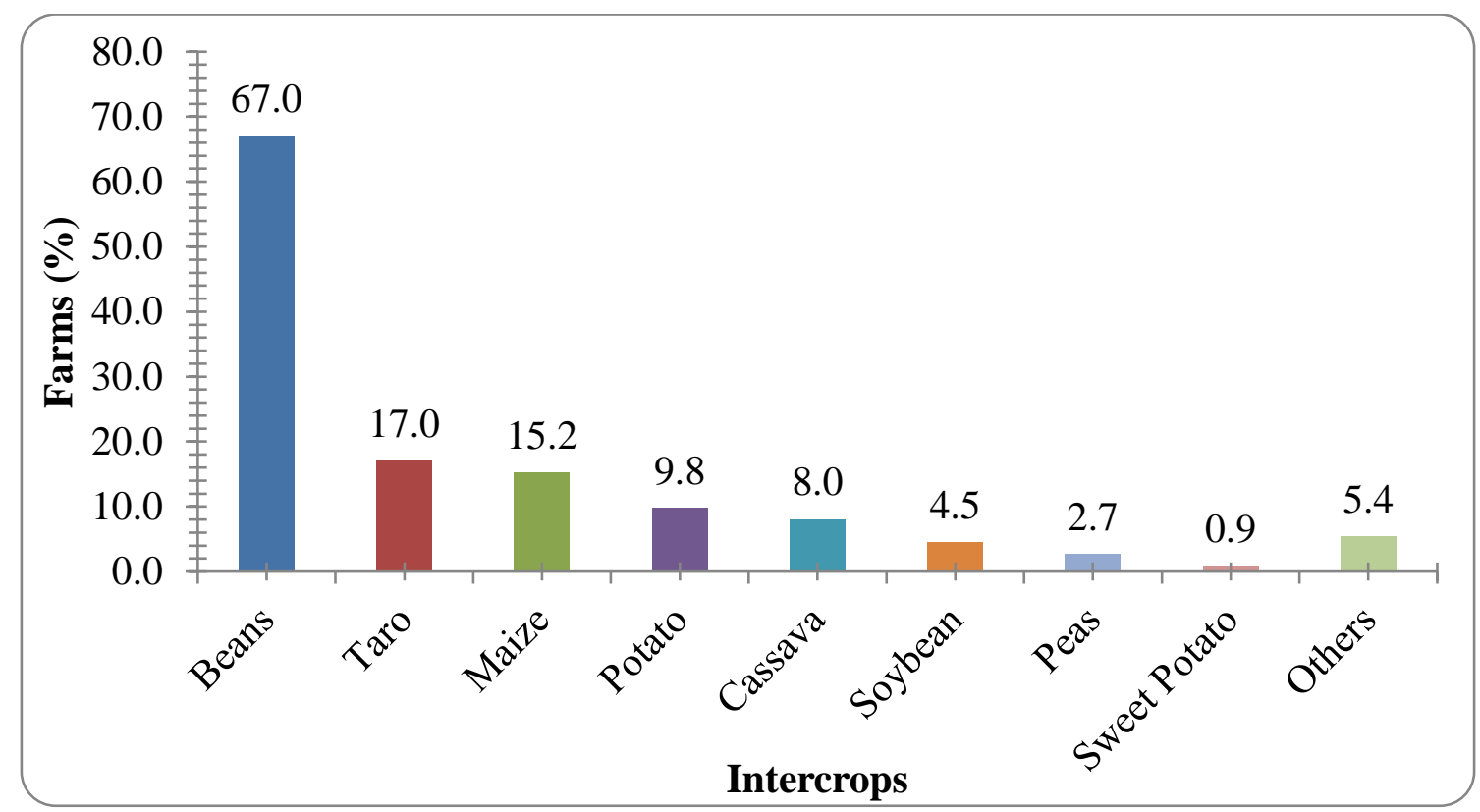

The main reason why farmers keep certain crops on their coffee plots is food security. Beans (Phaseolus vulgaris) are the favourite meal of Burundians. It is always part of the menu. It is served with banana (Musa sp.), with taro (Colocasia esculenta), with potato (Solanum tuberosum) or with cassava (Manihot esculenta) in the forms of cooked roots or as bread. Common bean is a nitrogen-fixing legume that is frequently integrated into coffee trees. Among all the cereals cultivated in Burundi, maize (Zea mays) occupies the first position. It is eaten in the form of roasted or cooked whole ears, in the form of cooked grains or in the form of corn paste. It can also be eaten as porridge. Studies integrating beans and other food crops in coffee plots have already been carried out in the EAC region, especially in Kenya. In Rwanda, for example, Harelimana et al. (2018) found that common beans (Phaseolus vulgaris L.) and soybeans (Glycine $\max$ L.) were the most coffee intercropped plants. An experiment in Kenya has concluded that coffee yields were not significantly affected by rows of beans (Mwakha et Ngugi 1990) while another experiment in Kenya on young coffee concluded that several food crops should be profitably intercropped with coffee (Njoroge \& Kimemia, 1995). However, this study excluded sweet potato and maize which had adverse effects (Njoroge, Waithaka \& Chweya, 1993).

\section{Diseases and Pests Management}

In the Great Lakes region and in Burundi (Lambot, 1988), the most serious pest for coffee is the coffee bug (Antestiopsis orbitalis ghesquierei Carr.). Fungal diseases such as anthracnose caused by Colletotrichum coffeanum Noack as well as rust

49 | This work is licensed under a Creative Commons Attribution 4.0 International License. 
caused by Hemileia vastatrix are also an important constraint on the coffee growing in the study area (Nibasumba 2013).

In the context of certification, the use of insecticide and fungicide is not permitted. As a result, we found in Gitega and Muramvya, a preparation used to control pests and diseases. They mix five plant species. These plants are Tephrosia vogelii (vernacular name: Intaruhunwa), Solanum aculeastrum (vernacular name: Intobotobo), Neorautanenia mitis (vernacular name: Intembe), Capsicum frutescens (vernacular name: Pilipili), and Tithonia diversifolia (vernacular name: Mukobwandagowe).

It is a mixture of plants that are used elsewhere in traditional medicine. For example:

- Tephrosia vogelii (Fabaceae), commonly known as Mexican sunflower or tree marigold, is widely used in the East African Region against various human diseases as having anti-inflammatory, analgesic, antimalarial, antiviral, antidiabetic, antidiarrheal, antimicrobial, antispasmodic, vasorelaxant, and cancer chemo preventive activities (Mkenda, Mtei, \& Ndakidemi 2014). It also has effects on grain yield and quality but this bio-pesticide is degraded by light (Mkenda et al., 2014). Acaricidal effects on tick have been also reported (Matovu \& Olila 2007).

- Solanum aculeastrum Dunal (Solanaceae), known as "goat bitter-apple," is a native of Africa. In South Africa, it has been used to treat various human and animal diseases, specifically stomach disorders and various cancers (Koduru, Grierson, \& Afolayan 2006). Two molecules (Solamagine and $\beta$-solamarine), extracted from the berries and root barks of Solanum aculeastrum Dunal, showed molluscicidal activity (Wanyonyi et al., 2002).

- Neorautanenia mitis (Fabaceae) is widely used in the management of diarrhoea (Dawurung et al., 2020) and has anthelmintic properties (Adebayo et al., 2018).

- Capsicum frutescens (Solanaceae) can be morphologically distinguished from other species of Capsicum by its smaller fruit size (Hegde et al., 2014). It has antibacterial activity and (Koffi-Nevry et al., 2012) has observed this against Vibrio cholerae, Staphylococcus aureus, and Salmonella typhimurium.

- Tithonia diversifolia (Asteraceae) is an invasive plant that is increasingly noticed in Burundi. Although there are some uses (but not published) of this plant in Burundi, studies have concluded about its anti-malarial activities, thanks to its Tagitinin C molecule (Goffin et al., 2002); and about its repellent activities (Oyewole et al., 2008). It can also be used for the treatment of painful inflammatory conditions (Owoyele et al., 2004).

All these plants are mixed to make a decoction. The resulting solution is sprayed to fight indiscriminately against coffee tree diseases. The chemical composition of this solution is not yet known. Also, the question of the dosage to be applied still remains.

\section{Soil Conditions}

Farmers show a deep understanding of the contribution of shade trees to soil fertility. Leaves that fall from trees help improve soil fertility in coffee plots because they decay in place. Fallen leaves also help to reduce evaporative losses from the soil that they cover. The soil remains wetter. The effect is more remarkable for Ficus sp. for which the interviewees affirm that "they water the coffee trees".

These results are in the same direction as those of Lin (2010) who concluded, in his study that shade cover creates a microclimate that promotes the reduction of the evaporative demand of the system, and maintaining the soil water available to the plants. The litter and its decomposition are visible in the plots. This probably explains why the role of shade trees in improving soil fertility is recognized. Grossman (2003) affirms that this comprehension is most likely due to their ability to see the decomposition process in action over time, as opposed to other processes that cannot be observed with the naked eye.

\section{Coffee Quality}

Upon their arrival at the coffee washing stations, the first assessment of the quality of cherries is done by 
floatation and the colour of the cherries. The best quality coffee is the one that is evenly ripe and does not float on water. These cherries are separated from the others and lead to "grade A" coffee quality.

Generally speaking, such coffee is produced on very fertile plots which are protected against diseases and pests. The interviewees state that thanks to the best water and fertility conditions under shade trees, coffee is forever green. The coffee trees under shade produce every year, despite the seasonality, leading to sustainable production. That's probably the reason why it is more difficult for farmers to proceed with the rejuvenation pruning of coffee trees that are under shade trees. This is in line with Wintgens (2004) for whom shaded coffee plants tend to be taller, more vigorous, and have higher leaf retention throughout the year compared to plants with little or no shade.

According to an important proportion of farmers (29\%), coffee ripening under shade trees is better when compared to coffee in full sun. They claim that coffee produced under shade weighs heavily, is of larger cherries, and has much mucilage. Interviewees also stated that cherries are uniformly red and their quality is improved under shade. This is in line with results from a study in Costa Rica which concluded on five main quality-based benefits from shading: (i) higher weights of fresh fruits, (ii) larger beans, (iii) higher ratings for the visual appearance of green and roasted beans, (iv) higher ratings for acidity and body, and (v) absence of off-flavors (Muschler, 2001).

As it is for the soil aspects, farmers mention visible aspects of the quality, such as the size of the cherries, and cherries that do not float in the water. These parameters are checked at the washing stations, and they lead to the acceptance or refusal of coffee production. Research in Hawaii has shown that shade produces larger beans but no impact on organoleptic quality (Steiman et al., 2011) while, in Ethiopia, Bote and Struik (2011) found advantages on both bean yield and quality. To our knowledge, such research has not yet been carried out in Burundi.

\section{CONCLUSION}

The initiative to improve the coffee sector through the introduction of certification in Burundi will go far if it is concerned with farmers' perception of this system. Through a household survey, this study has shown that farmers possess a deep understanding of the effects of shade trees on soil conditions in terms of fertility and soil moisture content. An important proportion of farmers $(75 \%)$ are involved in the process of getting organic certified. People exhibit less knowledge of the effects on coffee quality. For example, training sessions on the quality of coffee at washing stations according to its origin (shaded or full sun) would be useful. Also, we recommend training on crops that can be well associated with coffee. This study also showed that great efforts are made by farmers not to use chemicals in the control of diseases and pests by using a decoction made from five plants. An analysis of the composition of this decoction, as well as tests of its toxicity on different organisms, is necessary. This study may be an inspiration for future projects aiming at the sustainable development of the coffee sector.

\section{ACKNOWLEDGMENTS}

This study has been conducted under the funding of the Baden-Württemberg Region, Germany under the number SEZ 11/2019 / EZ_27.

\section{REFERENCES}

Adebayo, L. A., Olubisi, A. E., Adebisi, S., \& Idowu, M. O. (2018). Anthelmintic principles from the tuberous roots of Neorautanenia mitis (A. Rich) Verdcourt-Papilonaceae. Journal of Chemical Society of Nigeria, 43(4), 904-14.

Beer, J. (1987). Advantages, disadvantages and desirable characteristics of shade trees for coffee, cacao and tea. Agroforestry systems, 5(1), 3-13.

Bellhouse, D. R. (2014). Systematic Sampling Methods. In Wiley StatsRef: Statistics Reference Online. American Cancer Society.

Bidou, J. E. (1994). Burundi: L'engrenage caféier. In Tulet, J. C. Charlery, B, Baty. F, \&. Pilleboue, J., Paysanneries du café des hautes terres tropicales (pp. 146-76). Paris: Editions Karthala.

51 | This work is licensed under a Creative Commons Attribution 4.0 International License. 
Bote, A. D., \& Struik, P. C. (2010). Effects of shade on growth, production and quality of coffee (Coffea arabica) in Ethiopia. Journal of Horticulture and Forestry, 3(11), 336-41.

Cerdán, C. R., Rebolledo, M. C., Soto, G., Rapidel, B., \& Sinclair, F. L. (2012). Local knowledge of impacts of tree cover on ecosystem services in smallholder coffee production systems. Agricultural Systems, 110, 119-130.

Dawurung, C. J., Noitem, R., Rattanajak, R., Bunyong, R., Richardson, C., Willis, A. C., ... \& Pyne, S. G. (2020). Isolation of CFTR and TMEM16A inhibitors from Neorautanenia mitis (A. Rich) Verdcourt: Potential lead compounds for treatment of secretory diarrhea. Phytochemistry, 179, 112464.

De Beenhouwer, M., Van Geel, M., Ceulemans, T., Muleta, D., Lievens, B., \& Honnay, O. (2015). Changing soil characteristics alter the arbuscular mycorrhizal fungi communities of Arabica coffee (Coffea arabica) in Ethiopia across a management intensity gradient. Soil Biology and Biochemistry, 91, 133-139.

FAO. 2015. Training Manual for Organic Agriculture. FAO.

Goffin, E., Ziemons, E., De Mol, P., de Madureira, M. D. C., Martins, A. P., da Cunha, A. P., ... \& Frederich, M. (2002). In vitro antiplasmodial activity of Tithonia diversifolia and identification of its main active constituent: tagitinin C. Planta medica, 68(6), 543-545.

González, A. A., \& Nigh, R. (2005). Smallholder participation and certification of organic farm products in Mexico. Journal of rural studies, 21(4), 449-460.

Grossman, J. M. (2003). Exploring farmer knowledge of soil processes in organic coffee systems of Chiapas, Mexico. Geoderma, 111(34), 267-287.

Harelimana, A., Le Goff, G., Rukazambuga, D. T., \& Hance, T. (2018). Coffee production systems: Evaluation of intercropping system in coffee plantations in Rwanda. Journal of Agricultural Science, 10(9).
Hatungimana, A. (2008). Le café et les pouvoirs au Burundi. Les Cahiers d'Outre-Mer. Revue de géographie de Bordeaux, 61(243).

Hegde, S. V., Hegde, G. R., Mulgund, G. S., \& Upadhya, V. (2014). Pharmacognostic Evaluation of Leaf and Fruit of Capsicum frutescens (Solanaceae). Pharmacognosy Journal, 6(3), 14-22.

Israel, G. D. (1992). Determining Sample Size. Florida Cooperative Extension Service, University of Florida.

Kimonyo, J. P., \& Ntiranyibagira, D (2007). Réformes de la filière café au Burundi: perspectives d'avenir pour la participation, la prosperité et la paix. International Alert.

Koduru, S., Grierson, D. S., \& Afolayan, A. J. (2006). Antimicrobial Activity of Solanum aculeastrum. Pharmaceutical biology,44(4), 283-286.

Koffi-Nevry, R., Kouassi, K. C., Nanga, Z. Y., Koussémon, M., \& Loukou, G. Y. (2012). Antibacterial activity of two bell pepper extracts: Capsicum annuum L. and Capsicum frutescens. International journal of food properties, 15(5), 961-971.

Kufa, T. (2010). Environmental Sustainability and Coffee Diversity in Africa. Guatemala: International Coffee Organization.

Lambot, C. (1988). Les acquis de la recherche sur Coffea arabica L. dans la région des Grands Lacs (Zaïre-Rwanda-Burundi). Bujumbura.

Lin, B. B. (2010). The role of agroforestry in reducing water loss through soil evaporation and crop transpiration in coffee agroecosystems. Agricultural and forest meteorology, 150(4), 510-518.

Matovu, H., \& Olila, D. (2007). Acaricidal Activity of Tephrosia vogelii Extracts on Nymph and Adult Ticks. International Journal of Tropical Medicine 2(3), 83-88.

Mkenda, P. A., Mtei, K., \& Ndakidemi, P. A. (2014). Pesticidal efficacy of Tephrosia vogelii and Tithonia diversifolia against field insect 
pests of common beans [Phaseolus vulgaris L.] within African farming communities. African Journal of Applied Agricultureal Sciences and Technologies, 2 (1), 9-26.

Munyuli, T. (2011). Farmers' perceptions of pollinators' importance in coffee production in Uganda. Agricultural Sciences, 2(03), 318.

Muschler, R. G. (2001). Shade improves coffee quality in a sub-optimal coffee-zone of Costa Rica. Agroforestry systems, 51(2), 131-139.

Mwakha, E., et D. N. Ngugi. 1990. « Yield Advantage in Intercropping of High Density Arabica Coffee with Dry Beans ». East African Agricultural and Forestry Journal 56(2):21-26.

Nibasumba, A. (2013). Evaluation agronomique de l'association bananiers-caféiers: application au Burundi. Doctoral dissertation. Faculté d'Ingénierie Biologique, Agronomique et Environnementale Université Catholique de Louvain-la-Neuve (Belgique).

Niragira, S., D'Haese, M., D'Haese, L., Ndimubandi, J., Desiere, S., \& Buysse, J. (2015). Food for survival: Diagnosing crop patterns to secure lower threshold food security levels in farm households of Burundi. Food and nutrition bulletin, 36(2), 196-210.

Njoroge, J. M., \& Kimemia, J. K. (1995). Effects on the yield and growth of a young compact Arabica coffee hybrid of intercropping with food crops in three agro-ecozones in Kenya. Experimental Agriculture, 31(1), 49-55.

Njoroge, J. M., Waithaka, K., \& Chweya, J. A. (1993). Effects of intercropping young plants of the compact Arabica coffee hybrid cultivar Ruiru 11 with potatoes, tomatoes, beans and maize on coffee yields and economic returns in Kenya. Experimental Agriculture, 29(3), 373377.

Nyamoya, P., Kazungu, C., \& Akilimali, J. (1986). Burundi: Le Financement Du Développement La Filière Café. Revue Tiers Monde, 357-374.

Owoyele, V. B., Wuraola, C. O., Soladoye, A. O., \& Olaleye, S. B. (2004). Studies on the antiinflammatory and analgesic properties of
Tithonia diversifolia leaf extract. Journal of ethnopharmacology, 90(2-3), 317-321.

Oyewole, I. O., Adeoye, G. O., Anyasor, G. N., \& Obansa, J. A. (2008). Anti-malarial and repellent activities of Tithonia diversifolia (Hemsl.) leaf extracts. Journal of medicinal plants Research, 2(8), 171-175.

Steiman, S., Idol, T., Bittenbender, H. C., \& Gautz, L. (2011). Shade coffee in Hawai 'i-Exploring some aspects of quality, growth, yield, and nutrition. Scientia Horticulturae, 128(2), 152158.

Tessens, E., Sottiaux, G. \& Bigura, C. (1991). Classification des sols pour la carte pédologique du Burundi (1:50000). Bujumbura, Burundi: Institut des sciences agronomiques du Burundi.

Toledo, V. M., \& Moguel, P. (2012). Coffee and sustainability: the multiple values of traditional shaded coffee. Journal of Sustainable Agriculture, 36(3), 353-377.

Wanyonyi, A. W., Chhabra, S. C., Mkoji, G., Eilert, U., \& Njue, W. M. (2002). Bioactive steroidal alkaloid glycosides from Solanum aculeastrum. Phytochemistry, 59(1), 79-84.

Wintgens, J, N. (2004). Coffee: Growing, Processing, Sustainable Production. A Guidebook for Growers, Processors, Traders and Researchers. WILEY-VCH Verlag GmbH\&Co. KGaA. Weinheim: WILEY-VCH Verlag GmbH \& Co. KGaA.

53 | This work is licensed under a Creative Commons Attribution 4.0 International License. 